\title{
URGENCY LEGAL ASPECTS OF GROWTH INFORMATION TECHNOLOGY IN INDONESIA
}

\author{
Hardianto Djanggih \\ Doctoral Student, Department Criminal Law, Universitas Muslim Indonesia and Lecture \\ of Law Universitas Tompotika Luwuk, Indonesia \\ No. 67, Dewi Sartika Rd, Luwuk, Central Sulawesi, 94715, Indonesia \\ Hardianto_djanggih@yahoo.co.id \\ Hambali Thalib \\ Professor of Law, Universitas Muslim Indonesia, as Promotor \\ No.5, Urip Sumohardjo Rd, Makassar, South Sulawesi, 90231, Indonesia \\ hambali_thalib@yahoo.co.id \\ Hamza Baharuddin \\ Assistant Professor of Law, Universiras Muslim Indonesia, as co. Promotor \\ No.5, Urip Sumohardjo Rd, Makassar, South Sulawesi, 90231, Indonesia \\ hamza_baharuddin@yahoo.com \\ Nurul Qamar \\ Assistant Professor of Law, Universiras Muslim Indonesia, as co. Promotor \\ No.5, Urip Sumohardjo Rd, Makassar, South Sulawesi, 90231, Indonesia \\ nurulqamar@umi.ac.id
}

\begin{abstract}
The Article is aims to growth in information technology are the implications for human life. information technology can bring benefits to humans and may also have an effect. one effect is the cyber crime. Therefore, we need regulation to address the development of information technology. Regulation is needed as the state's responsibility to protect its citizens from the aspect of life. In Indonesia birth of regulation of information technology starting with the enactment of Law No. 11 of 2008 on Information and Electronic Transactions. However, in the growth of the Act are experiencing changes were very significant.
\end{abstract}


Keywords: Legal Aspects, Growth, Information Technology, Indonesia

\section{INTRODUCTION}

Internet and information technology is a new innovation in the last decade that affect human life (Hanim 2011). Since the turn of this century, the Internet has become a general purpose technology that contributed some $\$ 4$ trillion to the world economy in 2016 and connects nearly half the world's population (Joseph 2016) .

Security policy in the information age faces formidable challenges (Salleh et al. 2016). Cybercrime is a crime type produced from the development of Internet Nor are fears of cyberwar abstract speculation (Sun, Shih, and Hwang 2015). The era of cyber war has already arrived, this is indicated by the attacks of the Estonian and Georgian government websites, Stuxnet designed to disable Iran nuclear centrifuges, and the hacking of the U.S. military computer networks.(Erik Gartzke 2013) A need arose for the enactment of specific cyber legislation to address cybercrime"(Cassim 2010).

Indonesia with a constitutional state, based on the amendment Constitution of the Republic of Indonesia 1945, Article 1 (3): “The State of Indonesia shall be a contotutional state"(Indonesian 2002). Thus, the presence of information technology, Indonesia has legislate regulations governing information technology by Act No. 11 of 2008 on Information and Transactions. However, the presence of the law has not been able to answer the problem of information technology today.

\section{METHODOLOGY}

This research is a normative juridical research. The approach used in this research is statute approach and conceptual approach. Statutory approach is used to know and understand the laws related to information technology in Indonesia, while conceptual approach is important to conceptualize the information security technology model in Indonesia.

\section{RESULT \& DISCUSSION}


The survey results Users Association of Indonesian Internet Service (APJII) was released in November 2016, 132.7 million people Indonesia has been connected to the internet from a total population of Indonesia as much as 256.2 million people.

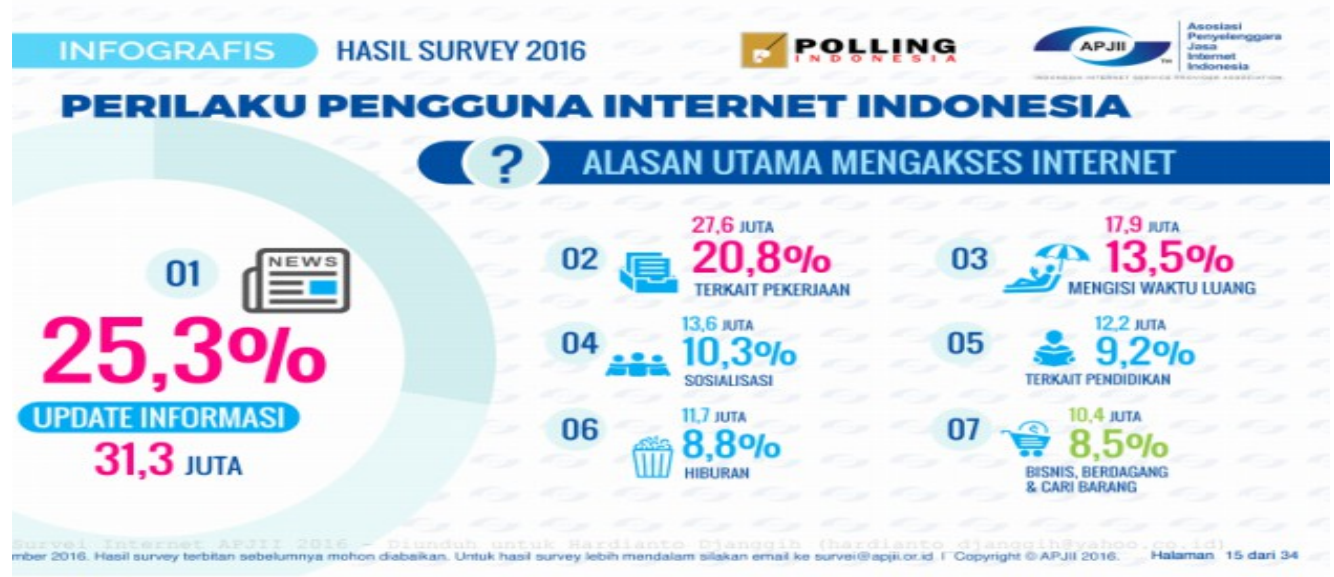

The Secondary data from the 2016 Survey APJII.

The results of internet users survey to update the data is the highest percentage is $25.3 \%$, and the lowest percentage for entertainment is $8.8 \%$.(APJII 2016) The survey results of APJII analogous with the opinion of Carlos A. Rohrmann, etc. He said that "the data can be retrieved anytime and anywhere through simple devices such as smartphones"(Rohrmann and Cunha 2015).

Security policy in the information age faces formidable challenges (Cello 2013). One of the challenges of regulation in the Internet era is how to set limits on government access to stored personal data (Woods 2016).

The use of computers and the internet involving almost all aspects of our daily life. (Uma and Padmavathi 2013). Interpret law violations computer raises an important new twist (Kerr 2017). Cermati Kenichi ohmae said the information technology raises implications and problems that need legal arrangements, including security (security) (Budhijanto 2014).

In Indonesia, have legislate the regulation No. 11 Year 2008 on Information and Electronic Transactions (UU ITE) is a response to the presence of a new era 
of information technology. However, the existence of UU ITE has made changes through the decision of the Constitutional Court (MK).

Changes UU ITE through the Constitutional Court Decision No. 20/PUUXIV/2016, dated June 22, 2016. through Judicial Review Novanto, with Amar Decision to grant changes of several articles, including Article 5 (1) and (2) and Article 44 of Law ITE NRI considered contrary to the Constitution of 1945. (Mahkamah Konstitusi 2016)

Through Amar Constitutional Court Decision No. 20/PUU-XIV/2016 Article 5 (1) and (2) and Article 44 NRI declared contrary to the Constitution of 1945. The Court stated that the ruling of the number 1 (1.1) The provision of Article 5 paragraph $(1,2)$ and Article 44 is contrary to the Constitution NRI 1945 to the extent not be interpreted as evidence conducted within the framework of law enforcement at the request of the police, the Public Prosecution, and / or other law enforcement institutions established by law as stipulated in Article 31 paragraph (3) UU ITE. The verdict dictum corroborated by verdict number 1 (1.2) The provision of Article 5 paragraph (1.2) and Article 44 of the EIT Law has no binding legal.

Linkages with the decision of the Court, that the Court is the court of first instance and the last. It is referred to in article 24 paragraph (1) NRI Constitution of 1945. The authority of the Constitutional Court as the sole interpreter of the Constitution NRI 1945 decision is final and binding - meaning that the decision taken by the Court - not to do legal remedy, both general remedies and extraordinary.(Fauzan 2009). So, to do Implications of Constitutional Court Decision No. 20 / PUU-XIV / 2016 against the articles of the proposed judicial review is no longer valid.

In progress of regulation that arrange growth of information technology, Indonesia Goverment legislate Regulation No. 19 of 2016 about amandement of regulation No. 11 of 2008 about information and electronic transaction.

Observe to the explanation inception of regulation No.19 of 2016 in the third paragraph said that regulation No. 11 of 2008 about Information and Electronic Transactions (UU ITE) is the first regulation in the part of Information 
Technology and Electronic Transaction as a new legislation is needed and has been became pioneers who laid the basic settings in the field of the use of Information Technology and Electronic Transactions. However, in fact, the implementation of UU ITE have problems.

General requirements in the problem means that there are four importaint reason, one of the reason is the regulations have been proposed several times for the materiil test in Constitutional Court by the Constitutional Court Decision No. 50 / PUU-VI / 2008, No. 2 / PUU-VII / 2009, No. 5 / PUU-VIII / 2010 and No. 20 / PUU-XIV / 2016.

Amandement of regulations associated with the principles of the law such as the principles of Lex Posteriori Derogat Legi Priori (New Regulations disregard old regulations), so the provisions prearranged in regulations No. 11 of 2008 about information and electronic transaction such as in this principle doesn't apply anymore and applicable provisions of the new regulations as stipulate in regulation No. 19 of 2016 about amandement og regulations No. 11 of 2008 about information and electronic transaction

\section{CONCLUSSION}

Regulations governing of the Growth information technology in Indonesia has significant changes. Begining the appearance of regulations No. 11 of 2008 about ITE as early milestone in the growth of law information technology in Indonesia its presence has not been answered the problems. The reason of dynamic growth of information technology is growing quite rapidly UU ITE has done Judicial Review in the Constitutional Court. So with the government law on political developments in information technology response regulations of (No.11 of 2008) amended regulations of No. 19 of 2016.

\section{BIBLIOGRAPHY}

APJII. 2016. "Penetrasi Dan Perilaku Pengguna Internet Indonesia." file://C:/Users/R11/Downloads/15XhPI3isVcBvw19GCnQD8zq6yWAFa (1).pdf.

Budhijanto, Danrivanto. 2014. "Peran Hukum Telekomunikasi Terhadap Implikasi 
Konvergensi Teknologi Informasi Dan Komunikasi." Jurnal Dinamika Hukum, Purwokerto: Fakultas Hukum Universitas Jenderal Soedriman 14 (1): $134-50$.

Cassim, Fawzia. 2010. "Addressing the Challenges Posed by Cybercrime: A South African Perspective." Journal of International Commercial Law and Technology 5 (3): 118-23.

Cello, Lucas. 2013. “The Permanence of Inconsistency.” International Security 38 (1): 7-40. doi:10.1162/ISEC.

Djanggih, H., \& Ahmad, K. (2017). THE EFFECTIVENESS OF INDONESIAN NATIONAL POLICE FUNCTION ON BANGGAI REGENCY POLICE INVESTIGATION (Investigation Case Study Year 2008-2016). Jurnal Dinamika Hukum, 17(2), 152-157.

Djanggih, H., \& Saefudin, Y. (2017). Pertimbangan Hakim Pada Putusan Praperadilan: Studi Putusan Nomor: 09/PID. PRA/2016/PN. Lwk Tentang Penghentian Penyidikan Tindak Pidana Politik Uang.Jurnal Penelitian Hukum DE JURE, 17 (3), 413-425

Erik Gartzke. 2013. "The Myth of Cyberwar Bringing War in Cyberspace Back Down to Earth." International Security 38 (1): 137-59. doi:10.1162/ISEC.

Fauzan, Muhammad. 2009. "Terobosan Hukum Mahkamah Konstitusi (Analisis Tentang Putusan MK Nomor: 41/PHPU . D-VI/2008)." Jurnal Dinamika Hukum, Purwokerto: Fakultas Hukum Universitas Jenderal Soedriman 9 (1): $1-10$.

Hanim, Lathifah. 2011. "Keabsahan Perjanjian Dalam Perdagangan Secara Elektronik ( E-Commerce ) Di Era Globalisasi." Dinamika Hukum, Purwokerto: Faultas Hukum Universitas Jenderal Soedirman 11 (Khusus): 59-67.

Indonesian, Republic of. 2002. "The 1945 Constitutional Of The State Of The Republic Of Indonesia." In , edited by Intergovernmental Panel on Climate Change, 1:1-30. Cambridge: Cambridge University Press. doi:10.1017/CBO9781107415324.004.

Joseph S. Nye Jr. 2016. "Deterrence and Dissasion in Cyberspace." International Security 41 (1): 44-71. doi:10.1162/ISEC.

Kerr, Orin S. 2017. "Norms of Computer Tresspass." Columbia Law Review 116 (4): 1143-83.

Mahkamah Konstitusi, Republik Indonesia). 2016. Salinan Putusan Mahkamah Konstitusi Nomor: 20/PUU-XIV/2016 1-105.

Mamulai, M., Djanggih, H., \& Wahab, M. (2017). Strength of Evidence of 
Electronic Media (Teleconference) In The Criminal Justice System. VRIJSPRAAK: International Journal of Law, 1(1), 1-20.

Rohrmann, Carlos A., and Juliana Falci Sousa Rocha Cunha. 2015. "Some Legal Aspects of Cloud Computing Contracts." Journal of International Commercial Law and Technology, Denmark: International Association of IT Lawyers Vol. 10 (Issue 1): 37-45.

Salleh, Nurhashikin Mohd, Siti Rahayu Selamat, Robiah Yusof, and Shahrin Sahib. 2016. "Discovering Cyber Terrorism Using Trace Pattern" 18 (6): 1034-40.

Sun, Jia Rong, Mao Lin Shih, and Min Shiang Hwang. 2015. "A Survey of Digital Evidences Forensic and Cybercrime Investigation Procedure." International Journal of Network Security 17 (5): 497-509.

Thalib, H., Rahman, S., Mamulai, M., \& Djanggih, H. (2017). Verification Through the Electronic Media (Teleconference) on the Court in Criminal Judicial System. ADRI International Journal Of Law and Social Science, 1(1), 1-9.

Uma, M., and G. Padmavathi. 2013. "A Survey on Various Cyber Attacks and Their Classification." International Journal of Network Security 15 (5): 39096.

Woods, Andrew Keane. 2016. "Against Data Exceptionalism." Stanford Law Review 68 (April): 1-65. 